\title{
ON THE STRUCTURE OF A DEEP SCATTERING LAYER ON THE COASTAL SHELF OFF BAHÍA MAGDALENA, BAJA CALIFORNIA, MEXICO
}

\section{COMPOSICIÓN DE UNA CAPA DE DISPERSIÓN PROFUNDA EN LA PLATAFORMA CONTINENTAL DE BAHÍA MAGDALENA, BAJA CALIFORNIA, MÉXICO}

\author{
Carlos J. Robinson' \\ Jaime Gómez ${ }^{2}$ \\ Virgilio Arcnas \\ ' Laboratorio de Ecología de Pesquerias \\ Instituto de Ciencias del Mar y Limnologia \\ Universidad Nacional Autónoma de México \\ Apartado postal 70-305 \\ CP 04510, México, DF \\ ${ }^{2}$ Departamento de Plancton y Ecología Marina \\ Centro Interdisciplinario de Ciencias Marinas, IPN \\ Apartado postal 592 \\ La Paz, Baja California Sur, C.P 23000, México
}

Recibido en mayo de 1995; aceptado en octubre de 1996

\begin{abstract}
The structure of an intense deep scattering layer off the southwest coast of Baja California, Mexico, is described using Isaacs-Kidd net trawl samples, Bongo samples and hydroacoustic records. Results demonstrate the dominance of three organisms: an euphausiid, Euphausia eximia Hansen 1911; a decapod of the fannily Galatheidat, Pleuroncodes planipes (Stimpson, 1860); and a fish of the family Photichthyidae, Vinciguerria lucetia (Garman, 1899). Using a SIMRAD EY-200 echosounder, with a working frequency of $200 \mathrm{kHz}$, and a Hydro Acoustic Data Acquisition System (HADAS), echoes were separated according to their target strength. Euphausiids were associaled with the -56 to $-62 \mathrm{~dB}$ target strength group, the red crabs with the -51 to $-55 \mathrm{~dB}$ group, and fishes with the -32 to $-50 \mathrm{~dB}$ group. Results indicate that organisms within the layer were not randomly distributed, but that they have an internal structure both in a horizontal and vertical dimension.
\end{abstract}

Key words: deep scattering layer, hydroacoustic, HADAS, Baja California.

\section{RESUMEN}

Se describe la composición especítica y estructura de una capa de dispersión profunda encontrada en el suroeste de la península de Baja California, México. Los muestreos se realizaron mediante arrastres con red Isaacs-Kidd, red Bongo y registros hidroacústicos. Los resultados demuestran la dominancia de tres especies: un eufáusido, Euphausia eximia Hansen 1911; un decápodo de la familia Galatheidae, Pleuroncodes planipes (Stimpson, 1860); y un pez de la familia Photichthyidae, Vinciguerria lucetia (Garman, 1899). Los ecos acústicos de la capa de dispersión profunda fueron separados de acuerdo con la fuerza de blanco usando una ecosonda SIMRAD EY-200. con una frecuencia de $200 \mathrm{kHz}$, y un programa denominado Hydro Acoustic Data Acquisition System (HADAS). 
los eufäusidos fueron asociados con un intervalo de fuerza de blancos cntere - -56 y -62 dB. las langostillas entre -51 y $-55 \mathrm{~dB}$, y los peces entre $-32 y-50$ dB. Los resultados indican que los organismos presentaron una distribución no azarosa dentro de la capa de dispersión profunda. esto es, luvieron una estructura interna tanto en sentido horizontal como vertical.

Palabras clave: capa de dispersión profunda, hidroacústica, IIADAS, Baja California.

\section{INTRODUCTION}

Dense concentrations of plankton and micronekton are common features is some areas of the ocean; they can frequently be found near the continental slope. These layers may limit the performance of sonars in detecting fish or other large targets (MacLennan and Simmonds. 1992). They are biological in origin and a number of attempts have been made to describe their vertical distribution as shown by the echosounders and determined by trawling and nets (c.g. Morton and MacLellan. 1992; GuerinAncey and David, 1993: Madureira et al.. 1993: Sameoto et al. 1993). However, since they may be constituted by a single species or by a complex assemblage of organisms (Tucker, 1951; Batzler et al. 1975; Barange et al. 1993), a detailed description of the specilic composition and structure of this kind of layers is a diflicult task.

Few studies have attempted to describe in detail the deep scattering layer (DSL). Within the California Current system. most of the acoustical research on the distribution of schools of tish, zooplankton aggregations and DSL, has been done in southern California (c.g., llewitt et al., 1976: Smith et al., 1989; Pieper et al. 1990; Greene et al., 1991; Napp et al. 1993). However, little attention has been paid to describe the most southern part of the California Current, particularly along Baja California.

The aim of the present work is to describe in two dimensions the structure, species composition and the distribution of the most abundant species of a huge DSL, using trawl nets, Bongo nets and an echosounder in an upwelling region off Bahía Magdalena. Mexico, recognized as one of the most productive zones along the southwest coast of Baja California (Roesler and Chelton. 1987: Hernández-Trujillo et al.. 1987).

\section{INTRODUCCIÓN}

Una caracteristica común en algunas áreas del océano son las elevadas concentraciones de plancton y micronecton. principalmente cerca de la plataforma continental. Ambos grupos son componentes de la capa de dispersión profunda (CDP). la cual es uno de los factores que puede limitar el registro sónico para detectar peces u otras fuerzas de blancos más intensas (MacLennan y Simmonds, 1992). La CDP es de origen biológico y se han realizado diversos intentos para describir su distribución vertical por medio de muestreo con redes y equipos hidroacústicos (Morton y Maclellan, 1992; Guerin-Ancey y David, 1993: Madureira et al. 1993; Sameoto et al. 1993). Algunos de estos trabajos describen solamente una especic. mientras que otros describen complejas asociaciones de organismos (Tucker. 1951; Batzler et al. 1975; Barange et al., 1993). Sin embargo. en la mayoría de las ocasiones. realizar la descripción detallada de la composición específica y la estructura de la CDP es complicado.

La mayor parte de las investigaciones hidroacústicas realizadas en el sistema de la Corriente de California han sido enfocadas a la distribución de peees y agregaciones de zooplancton en la parte sur de California (e.g.. Ilewitt et al. 1976; Smith et al., 1989; Pieper et al., 1990; Greene et al.. 1991: Napp et al.. 1993). Sin embargo, se ha puesto poca atención en la descripción de la CDP en la porción sur de la Corriente de California. particularmente a lo largo de Baja California.

E1 propósito de este trabajo es describir en dos dimensiones la composición especifica y la estructura de una CDP. usando muestras obtenidas con redes Isaacs-Kidd y Bongo. asi como por medio de registros hidroacústicos en una zona de surgencia localizada frente a Bahía Magdalena. México. Esta región es reconocida como una de las romas más productivas de la 


\section{MATERIALS AND METHODS}

On December 15, 1993, on board the R/V li l'uma an intense acoustic DSL was detected on the southwest coast of Baja California, Mexico (lig. 1). The layer was detected using a SIMRAD E Y - 200 echosounder with a working frequency of $200 \mathrm{kH} z$. The gain was 10 . each step representing a gain of $3 \mathrm{~dB}$; attenuation was set at $-15 \mathrm{~dB}$. power $\mathrm{l} / \mathrm{l}$. Echoes recorded with the echosounder were analyzed using a Hydro Acoustic Data Acquisition System (HADAS) (Walline et al., 1992). The latter is an echo-counting analysis system which transforms the received echodistribution into area densities and, hence. population estimates. The system is based on a combination of hardware and computer software, which together allow the digitizing and storing of hydroacoustic data. Echo-counting results are presented as individuals per hectare (ind $\mathrm{ha}^{-1}$ ). The acoustic sizes are in units of target strength (TS) and expressed in decibels (dB). Before the cruise, calibration was done using a standard target. The target was a homogeneous $1.3 \mathrm{~cm}$ diameter copper sphere. All recordings were made using the $40 \log \mathrm{R}$ time-varied gain (TVG) function.

The DSI was located 15 nautical miles $(28 \mathrm{~km})$ off the southwest coast of the peninsula of Baja California $\left(24^{\circ} 41.8^{\prime} \mathrm{N}, 112^{\circ} 25.8^{\prime} \mathrm{W}\right)$ at $18.00 \mathrm{~h}$ local time (Pacific Standard Time). The DSL was about $7 \mathrm{~km}$ long (fig. 2a) and about $76 \mathrm{~m}$ wide in its central part (fig. 2b). No measurements were done along the transversal axis.

Three sections of the DSL were defined: one at the extreme left of the layer (inshore): a central part, at the core of the layer; and a third at the right side of the layer (offshore) (fig. 2a). Each section was about $1.5 \mathrm{~km}$ long, with a separation of at least $1 \mathrm{~km}$ between each other.

\section{Mid-water trawl sampling}

Using an Isaacs-Kidd mid-water net, trawls were performed along the DSL (perpendicular to the coast). Starting at the inshore part of the layer, the net was lowered to $20 \mathrm{~m}$ and trawling was performed during $4 \mathrm{~min}$ at that depth; it was then lowered another $20 \mathrm{~m}$ and trawled for costa suroeste de Baja California (Roesler y Chelton. 1987: Hernández-Trujillo et al.. 1987).

\section{MATERIALES Y MÉTODOS}

El 15 de diciembre de 1993, a bordo del B/O El Puma, se encontró una densa CDP registrada en la parte suroeste de la peninsula de Baja California, México (fig. 1). L.a CDP fue registrada por medio de una ecosonda SIMRAD EY-200, con una frecuencia de $200 \mathrm{kHz}$. La ganancia fue 10 , cada intervalo representa una ganancia de $3 \mathrm{~dB}$, la atenuación fue determinada en $-15 \mathrm{~dB}$, y la potencia de $1 / 1$. Los registros acústicos fueron analizados usando el programa Hydro Acoustic Data Acquisition System (HADAS) (Walline et al., 1992). Éste consiste en un sistema de análisis de ecoconteo, el cual transforma la ecodistribución recibida en densidades por hectárea. El sistema es una combinación de hardware y software que permite la digitalización y almacenamiento de los datos hidroacústicos. Los resultados son presentados como individuos por hectárea (ind ha ${ }^{-1}$ ). Los tamaños de los blancos acústicos son expresados en unidades de fuerza de blan$\cos (\mathrm{FB})$ en decibelios (dB). Previo al crucero, la calibración de blancos fue realizada usando un blanco estándar. Éste fue una esfera homogénea de cobre de $1.3 \mathrm{~cm}$ de diámetro. Todos los registros fueron realizados usando la función $40 \log \mathrm{R}$ de ganancia de tiempo variable.

La CDP fue localizada a 15 millas naúticas de la costa $(28 \mathrm{~km})$, en la parte suroeste de la península de Baja California $\left(24^{\circ} 41.8^{\prime} \mathrm{N}\right.$, $112^{\circ} 25.8^{\prime} \mathrm{O}$ ), a las $18.00 \mathrm{~h}$ (tiempo estándar del Pacífico). La CDP fue de aproximadamente $7 \mathrm{~km}$ de largo (fig. $2 \mathrm{a}$ ) y cerca de $76 \mathrm{~m}$ de profundidad en su parte central (fig. 2b). Ninguna medición fue hecha en el eje transversal.

Se definieron tres secciones de la CDP: costera, central (la parte más densa de la capa) y oceánica (lig. 2a). Cada sección lue de aproximadamente $1.5 \mathrm{~km}$ de largo, con una separación de al menos $1 \mathrm{~km}$ entre cada una de ellas.

\section{Muestreo de media agua con red Isaacs-Kid}

Se realizaron tres arrastres a lo largo de la CDP (perpendiculares a la costa), utilizando 


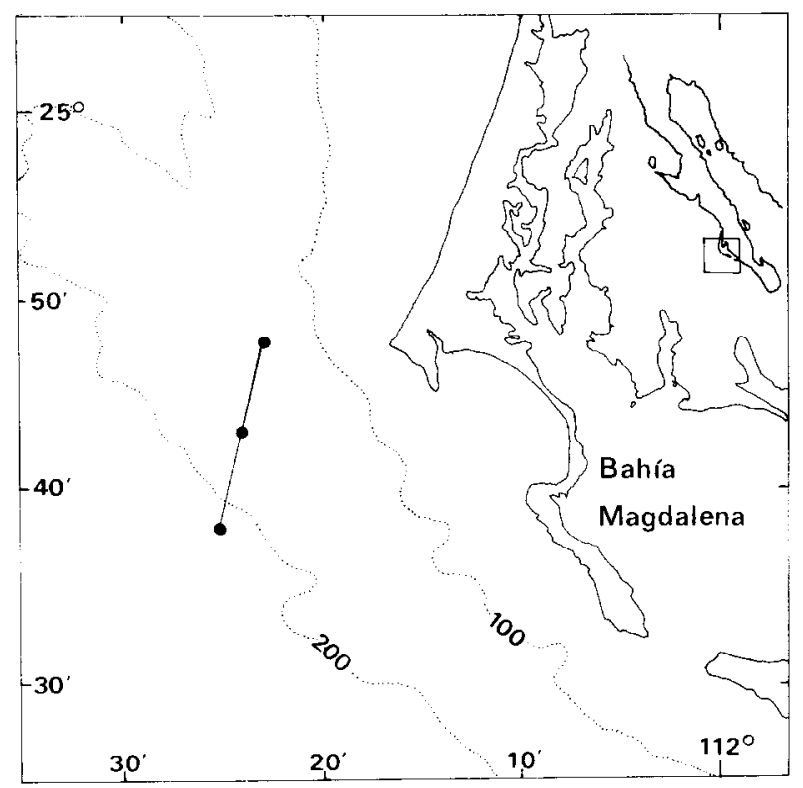

Figure 1. Study area.

Figura 1. Área de cstudio.

another $4 \mathrm{~min}$ and so on. until the deepest layer at $100 \mathrm{~m}$. In the end, we had five levels each with 4 min sampled (i.e., at 20,40, 60, 80 and $100 \mathrm{~m}$ ). A total of three Isaacs-Kidd trawls were made going forwards and backwards along the transect. Ship speed during the hauls was 4 knots.

\section{Bongo net sampling}

Zooplankton was collected at three oceanographic stations, one at each end of the DSL and one in the middle. Zooplankton samples were collected by means of Bongo nets fitted with a llowmeter (Gencral Oceanics) and with a $1,000-\mu \mathrm{m}$ mesh; the nets were lowed from $210 \mathrm{~m}$ (Smith and Richardson. 1977). The data for hiomass were normalized to $\mathrm{ml} 1.000 \mathrm{~m}^{-3}$. according to Beers (1976).

\section{Hydroacoustic counting and percentage of shoaling}

Acoustic information was generated and stored in a computer using $H \Lambda D A S$. Moreover. una red de media agua Isaacs-Kidd: éstos se iniciaron en la parte costera de la CDP. En cada arrastre, la red fue bajada a $20 \mathrm{~m}$ y arrastrada durante aproximadamente $4 \mathrm{~min}$ en esa profundidad; después se bajó otros $20 \mathrm{~m}$ y se arrastró durante otros $4 \mathrm{~min}$ y así sucesivamente hasta la capa más profunda de $100 \mathrm{~m}$. De esta forma, se hicieron cinco niveles con $4 \mathrm{~min}$ cada uno $(20,40,60,80$ y $100 \mathrm{~m})$. La velocidad del barco durante los muestreos fue de 4 nudos.

\section{Muestreo con red Bongo}

A lo largo de la CDP fueron recolectadas muestras de zooplancton en tres puntos; uno a cada extremo y otro en el centro. Las muestras se recolectaron por medio de redes Bongo con flujómetros (General Oceanics) y con una luz de malla de $1.000 \mu \mathrm{m}$. Las redes lueron arrastradas desde $210 \mathrm{~m}$ hasta la superficic (Smith and Richardson, 1977). I os datos para estimar biomasa fueron normalizados a $\mathrm{ml} 1.000 \mathrm{~m}^{3}$. de acuerdo con Beers (1976). 


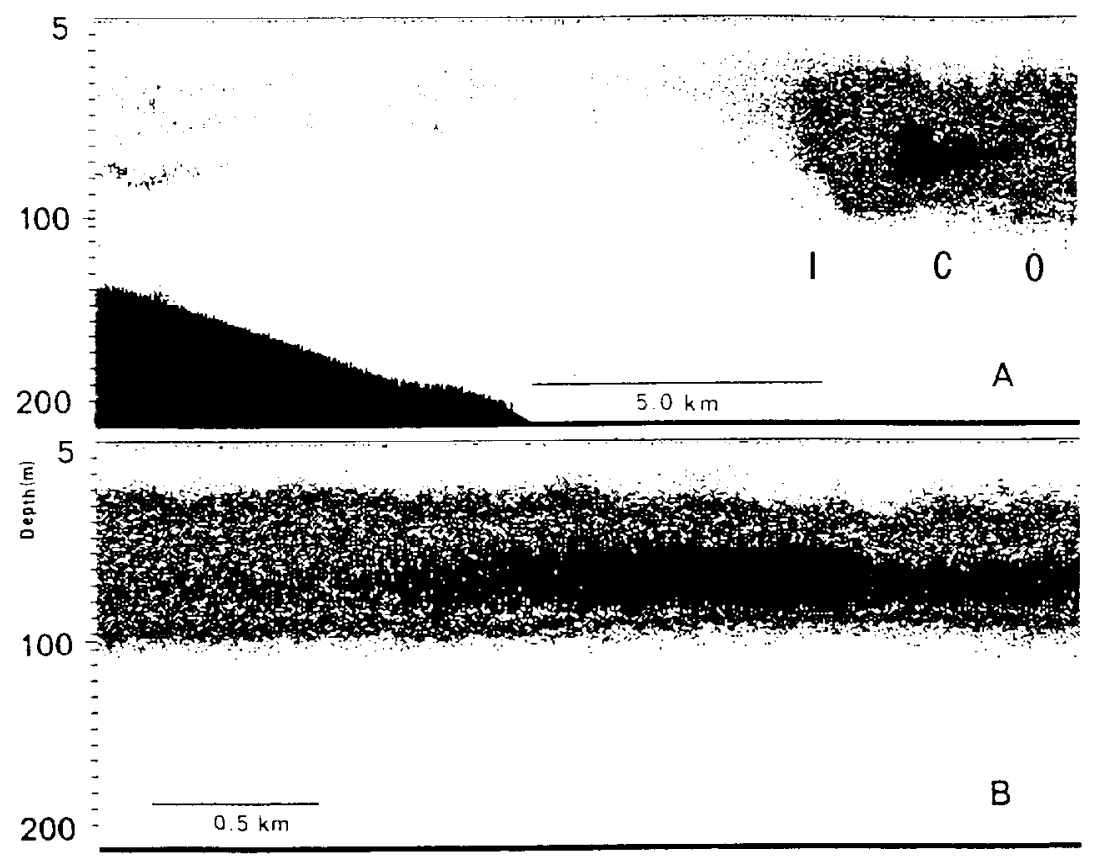

Figure 2. (A) Echogram showing the scattering layer: the slope at the left is the bottom. $I=$ inshore section, $\mathrm{C}=$ central section, $\mathrm{O}=$ offshore section. (B) A zoomed echogram showing the central part of the scattering layer; the darkest area is the densest part of the deep scattering layer.

Figura 2. (A) Ecograma mostrando la capa de dispersión. La plataforma continental en el lado izquicrdo. $\mathrm{I}=$ sección costera, $\mathrm{C}=$ sección central, $\mathrm{O}=$ sección oceánica. (B) Es un acercamiento de la parte central de la capa de dispersión; el área más oscura es la parte más densa.

HADAS calculates the percentage of individuals already analyzed for echo-counting which were found forming shoals. With a pulse duration of $1 \mathrm{msec}$ and sound velocity set at $1.500 \mathrm{~m} \mathrm{~s}$ '. the pulse length was $150 \mathrm{~cm}$. We arbitrarily fixed as 40 the maximum number of echoes in the water volume where HADAS considered separated organisms. For instance, if there were 50 echoes in a volume, then $25 \%$ of the sample was considered a shoal. Shoaling is presented as a percentage.

\section{RESULTS}

\section{Isaacs-Kidd mid-water trawl sampling}

The size and abundance of the most abundant organisms caught with the Isaacs-Kidd

\section{Conteo hidroacústico y porcentaje de agrupamiento}

La información hidroacústica generada fue almacenada en una computadora usando el programa hidroacústico. Junto con la estimación de biomasa, HADAS calcula también cl porcentaje de individuos que estuvieron formando agrupaciones. Considerando que la duración del pulso fue de 1 mseg y que la velocidad del sonido en el agua es de $1.500 \mathrm{~m} \mathrm{~s}^{-1}$, tenemos que la longitud de pulso es de $150 \mathrm{~cm}$. El volumen de agua sonificado por cada transmisión dependerá entonces de esta longitud de pulso y de la distancia en la que la señal se encuentre del transductor. Arbitrariamente se determinó que 40 fuera el número máximo de ecos registrados en un volumen de agua sonificado para considerar 
are shown in table 1. The DSL was composed of three main groups: the Euphausiaceans. mainly Euphausia eximia Hansen 1911: a decapod crustacean of the family Galatheidae. Pleuroncodes planipes (Stimpson. 1860); and a fish from the family Photichthyidae, l'inciguerra lucetia (Garman. 1899).

\section{Hydroacoustic analysis}

For each section. echoes along the water column were separated into three sizes according to their target strength: weak echoes ranging from -56 to $-62 \mathrm{~dB}$, medium echoes from -51 to $-55 \mathrm{~dB}$ and strong echoes from -32 to $-50 \mathrm{~dB}$. For each target strength group and each $10-\mathrm{m}$ layer. HADAS calculated the number of individuals per hectare (ind ha ${ }^{-1}$ ) and compactness, starting at $15 \mathrm{~m}$ and ending at $105 \mathrm{~m}$ depth.

The inshore section was dominated by the -51 to $-55 \mathrm{~dB}$ group along all the water column, with 8.617 ind ha ${ }^{-1}$ in the whole volume and presenting a peak of 2.667 ind ha ' between 25 and $35 \mathrm{~m}$ depth. The -56 to $-62 \mathrm{~dB}$ group was second in density along the watcr column, with 5.445 ind ha ${ }^{-1}$. peaking at 25 to $35 \mathrm{~m}$, with 2.133 ind $\mathrm{ha}^{-1}$. The -32 to $-50 \mathrm{~dB}$ group presented the lowest density. with 3,106 ind ha'. having the maximum density between 45 and $55 \mathrm{~m}$, with 792 ind ha ' (fig. 3a). The percentage of shoaling in this section was very similar and low for the three groups. The densest section of the column, $20 \%$ of shoaling. was found around $85 \mathrm{~m}$ depth (fig. $4 \mathrm{a}$ ).

The central section of the layer was the densest area, both in individuals per hectare and compactness. It was dominated by the -32 to $-50 \mathrm{~dB}$ group, with 13,705 ind $\mathrm{ha}^{-1}$ and a maximum of 3.847 ind ha $\mathrm{ha}^{-1}$ at $65 \mathrm{~m}$. The -51 10 $-55 \mathrm{~d} B$ group was next in density. with 5,369 ind ha'. peaking at 25 to $35 \mathrm{~m}$ depth, with 2.617 ind ha ${ }^{-1}$. The -56 to $-62 \mathrm{~dB}$ group was the least abundant, with 2,532 ind ha ${ }^{\prime}$ in the whole water column and a maximum density of 1.558 ind $\mathrm{ha}^{-1}$ between 25 and $35 \mathrm{~m}$ (fig. $3 \mathrm{~b}$ ). The maximum percentage of shoaling was presented by the -32 to $-50 \mathrm{~dB}$ group. Between 65 and $75 \mathrm{~m}$. nearly $100 \%$ of the organisms with this target strength were found in a los organismos agrupados. Por ejemplo. si se registran 50 ecos en un volumen dado. entonces el $25 \%$ de toda la muestra estuvo agrupada.

\section{RESULTADOS}

\section{Muestreo de media agua con red Isaacs-Kidd}

La CDP estuvo compuesta básicamente por tres grupos de organismos: los Euphausiaceos, con la especie Euphansia eximia Ilansen 1911; un crustáceo decápodo de la familia Galatheidae. Pleuroncodes planipes (Stimpson, 1860): y un pez de la familia Photichthyidae. Vinciguerria lucetia (Garman. 1899) (tabla 1).

\section{Análisis hidroacústico}

Para cada sección de la CDP se separaron los ecos en tres intervalos de acuerdo con su FB a lo largo de la columna de agua: los ecos débiles de -56 a $-62 \mathrm{~dB}$, los ecos moderados de -51 a -55 dB y los ecos fuertes de -32 a -50 dB. La densidad y porcentage de agrupamiento por cada grupo de FB fueron estimados en capas de $10 \mathrm{~m}$, desde los 15 a los $105 \mathrm{~m}$ de profundidad.

A lo largo de toda la columna de agua, la sección de la CDP más cercana a la costa estuvo dominada por el grupo de -51 a $-55 \mathrm{~dB}$, con un total de 8,617 ind $\mathrm{ha}^{-1}$. presentando un pico de 2,667 ind ha $^{-1}$ entre los 25 y $35 \mathrm{~m}$. El grupo de -56 a -62 dB fue el segundo en abundancia, con 5.445 ind ha', mostrando su mayor abundancia entre los 25 y $35 \mathrm{~m}$, con 2,133 ind $\mathrm{ha}^{-1}$. El grupo de -32 a $-50 \mathrm{~dB}$ presentó las menores densidades. 3.106 ind ha ${ }^{-1}$, teniendo su mayor densidad entre los 45 y $55 \mathrm{~m}$. con 792 ind ha ${ }^{-1}$ (fig. 3a). El porcentaje de compactación en esta sección fue similar y muy reducida para los tres grupos. La sección más densa de la columna con $20 \%$ de agrupamiento. se encontró alrededor de $\operatorname{los} 85 \mathrm{~m}$ de profundidad (tig. 4a).

La sección central fue la porción más abundante y compacta. Fue dominada por el grupo de -32 a -50 dls. con 13.705 ind ha ${ }^{\prime}$ totales. mostrando un pico de 3.847 ind ha ${ }^{\prime}$ a $\operatorname{los} 65 \mathrm{~m}$. He siguiente grupo en abundancia fue el de -51 a $-55 \mathrm{~dB}$, con 5,369 ind ha ', mostrando su mayor densidad entre 25 y $35 \mathrm{~m}$. con 
Table 1. Mean total length (millimeters) and mean abundance (individuals per tow) of the main components of the scattering layer recorded on the southwest coast of Baja California. Individuals were caught by Isaacs-Kidd net trawls $(n=3)$. The standard deviation is shown in parentheses.

Tabla 1. Longitud (milimetros) y aburidarcia promedio (individuos por lance) de los principales componentes de la capa de dispersión. Los organismos fueron recolectados con una red lsaacs-Kidd $(n=3)$. Se muestra la desviación estándar entre paréntesis.

\begin{tabular}{lcr}
\hline & Mean size & Mean abundance \\
\hline Euphatsia eximia & $2.07(0.19)$ & $2416.5(420.5)$ \\
Pleuroncodes planipes* & $1.30(0.31)$ & $407.5 \quad(12.5)$ \\
Vinciguerria lucetia & $3.86(0.49)$ & $214.5(105.5)$ \\
Phasiphaidac & $4.27(1.26)$ & $32.0 \quad(5.0)$ \\
Gelatinous organisms & Not counted & \\
\hline
\end{tabular}

* = Mean carapacc length.

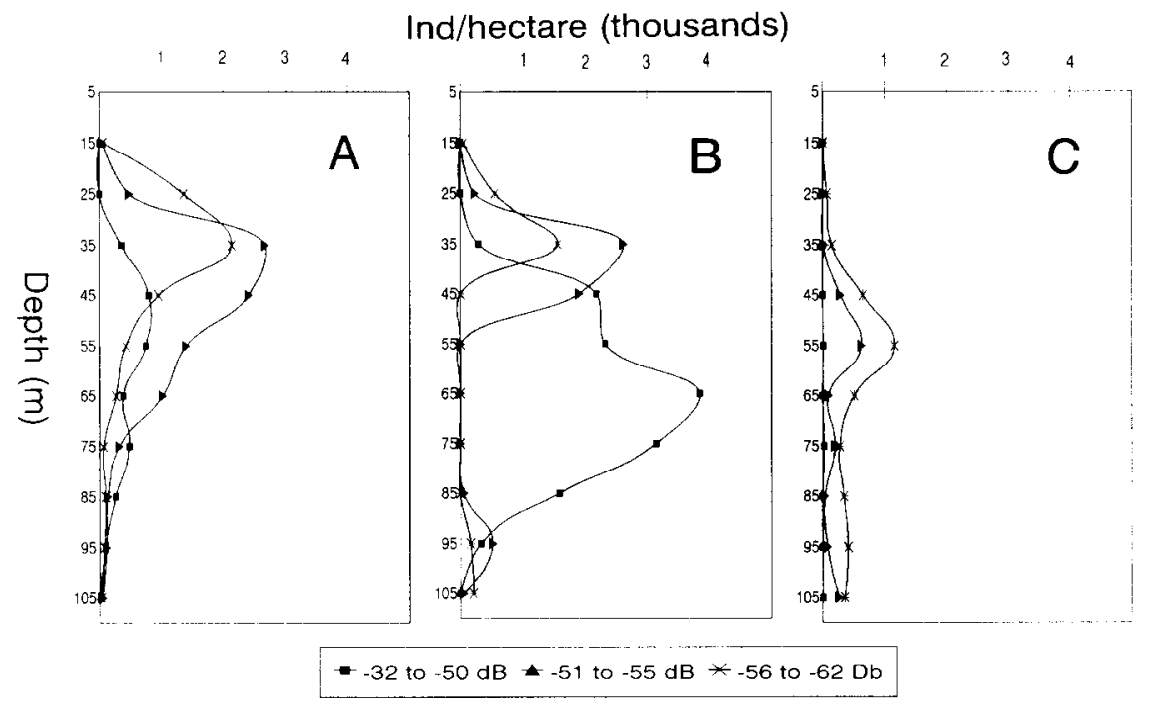

Figure 3. Density (individuals per hectare) along the water column for the (A) inshore. (B) central and $(C)$ offshore sections of the scattering layer. Density is presented in three diflerent groups of target strength, according to the echo intensity in decibels.

Figura 3. Abundancia (individuos por hectárea) registrada a lo largo de la columna de agua para la sección $(A)$ costera, (B) central y (C) oceánica de la capa de dispersión. La abundancia se presenta en tres diferentes grupos de fuerza de blancos, de acuerdo con la intensidad de los ecos en decibelios.

shoals. The value of shoaling for the other two groups was very low and quite similar, peaking at $95 \mathrm{~m}$ with $20 \%$ of shoaling (fig. $4 \mathrm{~b}$ ).

The offshore section of the layer was the jeast dense. The -56 to $-62 \mathrm{~dB}$ group dominated along the water column, with 5.455 ind ha '. peaking between 45 and $55 \mathrm{~m}$. with
2.617 ind ha $^{-1}$. El grupo de -56 a $-62 \mathrm{~dB}$ fue el menos abundante. 2.532 ind ha'. con una densidad máxima de 1.558 ind hal 'entre $25 y$ $35 \mathrm{~m}$ (fig. 3b). El máximo porcentaje de compactación lo tuvo el grupo de -32 a $-50 \mathrm{~dB}$. Los organismos de este intervalo de 1 B 3 encontrados entre los 65 y $75 \mathrm{~m}$ mostraron una 


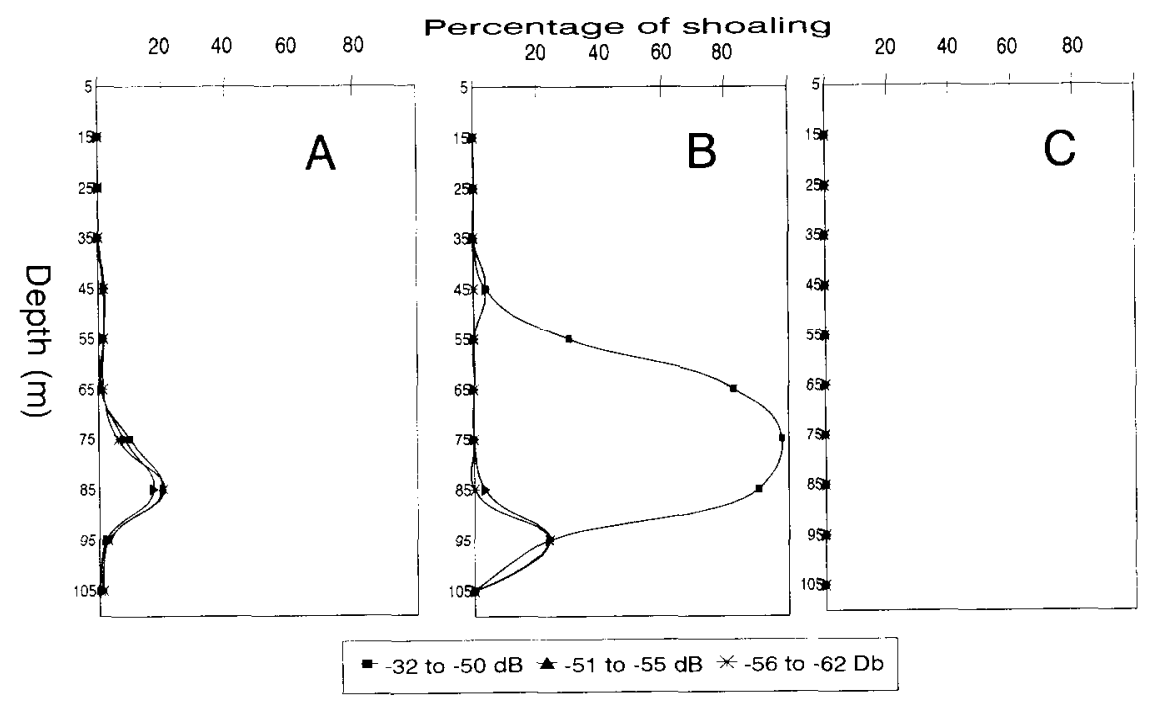

Figure 4. Degree of compactness (percentage of shoaling) of the organisms for the $(A)$ inshore. (B) central and (C) offshore sections of the scattering layer. The percentage of shoaling is presented for three different groups of target strength, according to the echo intensity in decibels.

Figura 4. Grado de compactabilidad (porcentaje de agregación) de los organismos para la sección (A) costera, (B) central y (C) oceánica de la capa de dispersión. El porcentaje de agregación se presenta en tres diferentes grupos de fuerza de blancos, de acuerdo con la intensidad de los ecos en decibelios.

1.159 ind $\mathrm{ha}^{-1}$. The -51 to $-55 \mathrm{~dB}$ group was second in abundance, with 1,585 ind ha ${ }^{1}$ and the highest density between 45 and $55 \mathrm{~m}$, with 623 ind ha '. The group with the strongest echoes presented the lowest density of the three sections, with 34 ind $\mathrm{ha}^{-1}$ in the whole water column, and peaking between 65 and $75 \mathrm{~m}$. with 21 ind $\mathrm{ha}^{-1}$ (fig. $3 \mathrm{c}$ ). In this section. the percentage of shoaling was zero for all the organisms (fig. 4c).

\section{Bongo net samples}

Four euphausiid species and red crab larvae dominated the samples. Only E. eximia and Nyctiphanes simplex Hansen, 1911 were also captured with the Isaacs-Kidd samples.

Mean sea surface temperature was $23.1^{\circ} \mathrm{C}$, and salinity, 34.75 .

\section{DISCUSSION}

An important issue in this study is to know the relation between echo-intensity and compactación cercana al $100 \%$. L os valores de compactación para los otros dos grupos fueron casi iguales y muy reducidos, siendo más compactos $(20 \%$ ) a los $95 \mathrm{~m}$ (fig. $4 \mathrm{~b}$ ).

La sección oceánica de la CDP fue la menos densa. El grupo que dominó cn abundancia a lo largo de la columna de agua fue $\mathrm{de}-56 \mathrm{a}-62 \mathrm{~dB}$, con 5,455 ind ha ', mustrande su mayor abundancia entre 45 y $55 \mathrm{~m}$. con 1,159 ind $\mathrm{ha}^{-1}$. El grupo de -51 a $-55 \mathrm{~dB}$ fue el segundo en abundancia, con 1.585 ind ha $^{-1}$ totales, y su mayor densidad entre 45 y $55 \mathrm{~m}$,

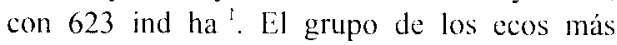
intensos presentó las más bajas densidades de las tres secciones, con 34 ind ha ' en toda la columna de agua, incrementando su abundancia entre 65 y $75 \mathrm{~m}$. con 21 ind ha ${ }^{~(f i g . ~} 3 \mathrm{c}$ ). En esta sección, el porcentaje de agrupación fue de cero para los tres grupos (lig. $4 \mathrm{c}$ ).

\section{Muestreo con red Bongo}

Cuatro especies de eufáusidos y larvas de la langostilla dominaron la muestra (tabla 2). 


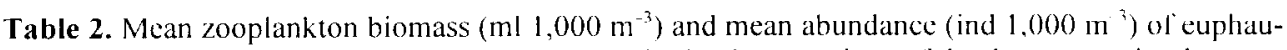
siids and red crab larvae collected with Bongo net in the three sections of the deep scattering layer.

Tabla 2. Biomasa media zooplanctónica $\left(\mathrm{ml} 1.000 \mathrm{~m}^{-3}\right.$ ) y abundancia media (ind $1.000 \mathrm{~m}^{3}$ ) de eufáusidos y larvas de langostilla recolectadas con red Bongo en las tres secciones de la capa de dispersión profunda.

\begin{tabular}{lccc}
\hline & Inshore section & Central section & Offshore section \\
\hline Zooplankton biomass & 2.80 & 0.65 & 2.50 \\
Euphausiid biomass & 0.18 & 0.25 & 0.40 \\
Nyctiphanes simplex & 35.37 & 17.68 & 1709.46 \\
Euphausia eximia & 82.52 & 44.21 & 88.42 \\
Euphausia distinguenda & 35.37 & & 70.74 \\
Stylocheiron affine & 35.37 & & 309.47 \\
Pleuroncodes planipes & 35.37 & & \\
\hline
\end{tabular}

organisms sampled, that is, the intensity of the echoes which organisms correspond to. Since we did not use trawls with multiple opening and closing nets (e.g., Sameoto et al., 1977; Sameoto, 1980; Everson, 1982), nor did we sample specific parts of the DSL, we cannot describe the particular species composition and abundance by depth or along the DSL throughout the Isaacs-Kidd sampling.

Even though this study presents evidence about the organisms found in the water column, several problems arise. First, a single-beam transducer may not be adequate for analyzing size distribution in enough detail to discriminate between organisms. Second, one is confronted by the selective effects of the net and the echosounder. which may neglect a large proportion of the animals and sound-scattering spectra. Third, catches from Isaacs-Kidd mid-water net hauls made in DSLs of low population density may be so small as to prevent any conciusion being drawn from them. Fourth, no matter how strong the correlation between the observed scattering and the catch, one is not certain that the animals captured are indeed the agents responsible for the observed scattering.

However, in this work we can correlate different groups of target strengths with the main organisms found in the samples. During the cruise, about 180 nautical miles north $\left(27^{\circ} \mathrm{N}, 114^{\circ} \mathrm{W}\right)$, we followed during a daily cycle the biomass variation of cuphausiids caught with vertical Bongo net tows $(1,000-\mu \mathrm{m}$ mesh size) and the density was estimated with
Solamente E. eximia y Nyctiphanes simplex Hansen, 1911 fueron capturadas también con red lsaacs-Kidd.

La temperatura superficial registrada durante el muestreo fue de $23.1^{\circ} \mathrm{C}$, con una salinidad de 34.75 .

\section{DISCUSIÓN}

Es importante conocer la relación entre la intensidad de ecos y la composición especifica $y$ abundancia de los organismos recolectados por medio de la red, es decir, la intensidad del eco a qué clase de organismo corresponde. Debido a que no se utilizaron redes múltiples de apertura y cierre automáticos (e.g. Sameoto et al., 1977; Sameoto, 1980; Everson, 1982), ni se hicieron muestreos en partes específicas de la CDP, no es posible describir la composición de especies y abundancia en cada estrato de la columna de agua o a lo largo de la CDP, muestreada únicamente con la red Isaacs-Kidd.

Por esta razón. aunque este estudio presenta evidencias acerca de los organismos encontrados en la columna de agua, existen varios problemas que deben ser analizados. Primero, el uso de un solo haz acústico puede no ser adecuado para analizar la distribución de talla con suficiente detalle para distinguir organismos. Segundo, existe el problema del efecto selectivo de la red y de la ccosonda, los cuales pudieran no considerar una proporción de los organismos y del espectro sónico de la CDP. Tercero. las capturas realizadas con la red de 
the echosounder. This analysis shows a strong relationship between the euphausiid biomass and the -56 to -62 dB group density (fig. 5). Similarly. Tucker (1951), using a $18 \mathrm{kHz}$ echosounder. correlated weak echoes with euphausiids from a DSL in southern California. Weibe et al. (1990), using a $420 \mathrm{kHz}$ echosounder, correlated the abundance of rooplanktonic crustaceans to a larget strength between -51 and $-88 \mathrm{~dB}$. (ireene et al. (1988), using a $420 \mathrm{kH} \%$ dual-beam echosounder, found that the most abundant acoustical size class was approximately -62 to $-71 \mathrm{~dB}$ for adult euphausiids in the Gulf of Maine.

During the cruise. we made several IsaacsKidd net trawls along the west coast of Baja California and the hydroacustical results sluwed a great proportion of echoes ranging from -51 to $-56 \mathrm{~d} 13$. The samples of these trawls were composed mainly of $P$. planipes, which were similar in carapace length to those found during the sampling of the DSL.

linally. since echo energy depends mainly on the difference in density between the rellecting organ and the water surrounding the lish (Maclennan and Simmonds. 1992). the strong echo group $(-32$ to $-50 \mathrm{~dB})$ was associated with $V$. lucetia, a fish with a swimbladder. which induces most of the strong back-scattering effect (Foote, 1980). Tucker (195I) correlated strong scattering with bathypelagic fishes, mainly myctophids with gaslilled swim-bladders.

Recent studies have described the internal structure of DSLs, demonstrating different distribution patterns according to species and population structure within species (Greene et al. 1991. 1992; Barange et al., 1993; Cochrane (t al. 1994). In the present work, the hydroacoustic results show that organisms with different target strength were not distributed at random within the layer, but that an internal structure does exist, in density and compactness.

The fish $V$. lucetia, the red crabs $P$. planipes and the euphausiid E. eximia are part of a common assemblage of species found on the southwest coast of Baja California. Loeb et al. (1983) reported the structure community of ichthyoplankton in the California Current and, in media agua Isaacs-Kidd en regiones donde la CDP presenta densidades reducidas, pueden ser demasiado bajas para obtener conclusiones adecuadas acerca de la estructura interna de la CDP. Cuarto. no importa que tan estrecha sca la relación entre la CDP registrada y las capturas obtenidas con redes; en realidad siempre existe incertidumbre de que los que se han capturado sean realmente los responsables de los ecos obtenidos.

Sin embargo, en este trabajo es posible relacionar los diferentes grupos de lib con los principales organismos encontrados en las recolecciones. Durante el crucero oceanográlico se realizó un ciclo diurno de la variación de la biomasa de eufáusidos capturados con arrastres verticales. Mediante una red Bongo $(1,000 \mu \mathrm{m}$ luz de malla), se registraron las densidades estimadas con la ecosonda en una localidad ubicada acerca de 180 millas náuticas al norte $\left(27^{\circ} \mathrm{N}, 114^{\circ} \mathrm{O}\right)$. A partir de este análisis, se encontró una estrecha relación entre la biomasa de eufáusidos y el grupo de -56 a -62 dB, los cuales fueron los ecos acústicos más débiles (1ig. 5). De manera similar, Tucker (1951), usando un transductor de $18 \mathrm{k} / \mathrm{z}$. correlacionó los ecos más débiles con eufáusidos encontrados en la CDP al sur de California. Weibe et al. (1990). usando una frecuencia de $420 \mathrm{kll} \%$. correlacionó la abundancia de crustáccos zooplanctónicos con un amplio intervalo de FB. comprendido entre -51 y $-88 \mathrm{~dB}$. (ireene et al. (1988), usando un transductor de haz doble con una frecuencia de $420 \mathrm{kHz}$. encontraron que el intervalo de lallas acústicas más abundantte fue de aproximadamente -62 a $-71 \mathrm{~dB}$ para cufáusidos adultos en el Golfo de Maine.

Durante el crucero, se realizaron varios muestreos con la red Isaacs-Kidd a lo largo de la costa occidental de Baja California, en regiones donde los registros hidroacústicos mostraron una clara dominancia de $\mathrm{FB}$ entre -51 y $-56 \mathrm{~dB}$. Las capturas obtenidas con la red Isaacs-Kidd en esta zona estuvieron compuestas casi en su tolalidad por $P$. planipes. Estas langostillas presentaron similares tallas de caparazón a las muestreadas en la CDP.

Finalmente, la FB en peees depende principalmente de la diferencia en la densidad del órgano reflector (la vejiga natatoria) con 


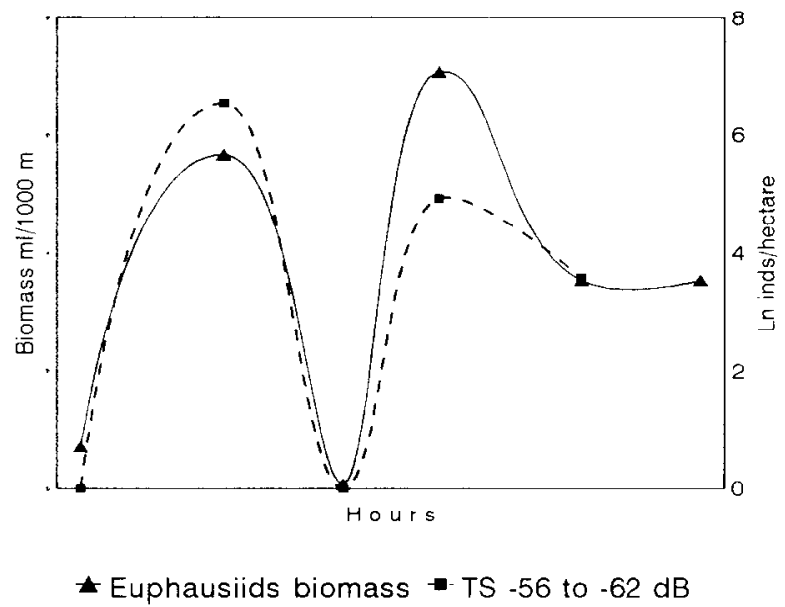

Figure 5. Density (individuals per hectare) calculated using HADAS for the target strength group of -56 to $-62 \mathrm{~dB}$ and euphausiid biomass obtained with a Bongo net during a daily cycle.

Figura 5. Abundancia (individuos por hectárca) calculada usando $\mathrm{cl}$ programa HADAS para la fuerza de blancos de $-56 \mathrm{a}-62 \mathrm{~dB}$ y la biomasa de eufáusidos obtenida con red Bongo durante un ciclo circadiano.

the most southern part of this current, $V$. lucetia was an important part of the assemblage of fishes in this region. According to Schulz (1976) and Aurioles-Gamboa (1992), the central distribution of the red crabs is found close to Bahía Magdalena, which is the main reproduction area of this species and where a permanent population could remain throughout year.

Gómez (1995) found a permanent population of E. eximia offshore, close to Bahía Magdalena $\left(24^{\circ}\right.$ to $\left.25^{\circ} \mathrm{N}\right)$, showing densities of adults ranging from 24 to 81 ind $1,000 \mathrm{~m}^{-3}$. The present paper seems to be the first record of a dense swarm of E. eximia, suggesting that this species could play an important role in the biological production in this region. According to Lavaniegos-Espejo (1994) and Gómez (1996), the species $N$. simplex is the most abundant euphausiid along the west coast of Baja California and the Gulf of California; however, no abundant swarm of this species was caught with the Isaacs-Kidd mid-water net, probably because of its small size $(<1.7 \mathrm{~cm})$, compared to the larger size of E. eximia $(<2.6 \mathrm{~cm})$. Using samples obtained with the Bongo net in the same area where the DSL el agua que rodea al pez (MacLennan y Simmonds, 1992). De esta forma, el grupo de los ecos más intensos $(-32$ a $-50 \mathrm{~dB})$ fue asociado con peces que, de acuerdo con la composición específica encontrada, correspondió principalmente a $V$. lucetia, un pez quc posee vejiga natatoria, el cual induce un efecto de reflexión sónica muy intensa (Foote, 1980). Similarmente, Tucker (1951) correlacionó los ecos acústicos más intensos con peces batipelágicos, principalmente mictófidos, los cuales poseen vejiga gaseosa.

Estudios recientes han descrito la estructura interna de la CDP, demostrando que ésta tiene patrones de distribución diferentes dependiendo de la composición de especies y aun de la estructura poblacional de éstas (Greene et al., 1991, 1992; Barange et al., 1993; Cochrane et al., 1994). En el presente trabajo, los resultados hidroacústicos mostraron que los organismos presentaron una distribución no azarosa dentro de la CDP. Esto es, se encontró una estructura interna tanto en abundancia como en grado de agrupamiento.

El pez $V$. lucetia, la langostilla $P$. planipes y el eufáusido E. eximia son las especies que comúnmente dominan en la composición 
was recorded, we found $E$. eximia, $N$. simplex, liuphausia distinguenda Hansen, 1911, Euphausia tenera Hansen, 1905, and larvae of the red crab $P$. planipes, which could be part of dense swarms of weak echoes detected by the echosounder. Except for E. eximia and $N$. simplex, the rest of the euphausiids and larval stages of the red crab were not caught with the Isaacs-Kidd net

The present study is one of the first approaches to determine the relationships between the dominant species found in a DSI on the southwest coast of Baja California and the target strength recorded in the water column. future research should focus on identifying the target strength of these organisms in terms of their size and degree of compactness, and determining their distribution and movement patterns within the scattering layer.

\section{ACKNOWLEDGEMENTS}

We are grateful to all the students of the Fisheries Ecology Laboratory at the ICMyL and the El Puma crew for their cooperation. This research was supported by the National Council for Science and Technology, Mexico (CONACYT 0511-N9108), and by the Dirección de Estudios de Posgrado e Investigación (DEPI 903361). Authors are supported by a fellowship from the Sistema Nacional de Investigadores and the second author is also supported by a COFAA-IPN fellowship.

\section{REFERENCES}

Aurioles-Gamboa, D. (1992). Inshore-offshore movements of pelagic red crabs Pleuroncodes planipes (Decapoda, Anomura, Galatheidae) off the Pacific coast of Baja California Sur, Mexico. Crustaceana. 62: 71-84.

Barange, M., Miller, D.G.M., Hampton, I. and Dunne. T.T. (1993). Internal structure of Antarctic krill Euphausia superba swarms based on acoustic observations. Mar. Ecol. Prog. Ser., 99: 205-213.

Batzler, W.E., Reese, J.W. and Friedl, W.A. (1975). Acoustic volume scattering: its dependence on frequency and biological especifica en la purción sur de la península de Baja California. Loeb et al. (1983) mencionan que $r$. lucetia es una especie bastante abundante en la estructura de la comunidad del ictioplancton al sur de la Corriente de California. De acuerdo con Schulz (1976) y Aurioles-Gamboa (1992), el centro de distribución de la langostilla se encuentra frente a Bahía Magdalena, siendo la principal área de reproducción de la especie, y donde una parte de la población puede permanecer durante todo el año.

Gómez (1995) encontró una población permanente de E. eximinia localizada en la parte oceánica cerca de Bahía Magdalena $\left(24^{\circ}\right.$ a $25^{\circ} \mathrm{N}$ ), presentando abundancias entre $24 \mathrm{y}$ 81 ind $1,000 \mathrm{~m}^{-3}$. Aparentemente, el presente estudio es el primer registro de un denso enjambre de E. eximia; estos resultados sugieren que esta especie puede constituir una contribución importante a la producción biológica de esta región. De acuerdo con Lavaniegos-Espejo (1994) y Gómez (1996), el eufáusido más abundante en la costa occidental de Baja California $y$ el Golfo de California es $N$. simplex; sin embargo, éste no fue capturado con la red Isaacs-Kidd, probablemente debido a su menor talla $(<1.7 \mathrm{~cm})$ en comparación con E. eximia $(<2.6 \mathrm{~cm})$. Con las muestras de la red Bongo se encontraron las especies E. eximia, $N$. simplex, Euphausia distinguenda Hansen, 1911 y Euphausia tenera Hansen, 1905, así como larvas de la langostilla $P$. planipes, que pudieron ser parte del denso enjambre registrado por el ecosonda como ecos débiles, de -56 a $-62 \mathrm{~dB}$. Excepto E. eximia y algunos especímenes de $N$. simplex, el resto de los eufáusidos y los estadios larvarios de la langostilla no fueron recolectados con la red lsaacs-Kidd. Los arrastres de Bongo fueron más profundos que los arrastres de Isaacs-Kidd. Probablemente estas especies y las larvas de langostilla sólo se encuentren a mayores profundidades.

[.] presente estudio es una de las primeras aproximaciones para determinar la relación entre las especies más abundantes y la FB acústicos registrados en la columna de agua, encontradas en la costa suroeste de Baja California. Futuras investigaciones deben ser enfocadas a identificar la FB de los organismos más abundantes en función de su talla y el grado de 
scatterers. Undersea Surveillance and Ocean Sciences Department, Naval Undersea Center, San Diego, NUC TP, 442: 1-22.

Beers, I.R. (1976). Volumetric methods. In: H.F. Steedmann (ed.), Zooplankton Fixation and Preservation. Monographs on Oceanographic Methodology, Vol. IV, UNESCO, Paris, pp. 54-60.

Cochrane, N.A., Sameoto, D.D. and Belliveau. D.J. (1994). Temporal variability of euphausiids concentrations in a Nova Scotia shelf basin using a bottom-mounted acoustic doppler current protiler. Mar. Ecol. Prog. Ser. 107: 55-66.

Eversurl, I. (1982). Diurnal variations in mean volume backscattering strength of an Antarctic krill (Euphausia superba) patch. J. Plankton Res., 4: 155-163.

Foote, H.G. (1980). Importance of the swimbladder in acoustic scattering by fish: a comparison of gadoid and mackerel target strengths. J. Acoust. Soc. Am., 67: 2084-2089.

Gómez, G.J. (1995). Distribution patterns, abundance and population dynamics of the euphausiids Nyctiphanes simplex and Euphausia eximia off the west coast of Baja California, Mexico. Mar. Ecol. Prog. Ser., 19: 63-76.

Gómez, G.J. (1996). Ecology of early larval development of Nyctiphanes simplex Hansen (Euphausiacea) off the southwest coast of Baja California, Mexico. Bull. Mar. Sci., 58(1): 131-146.

Greene. G.H., Weibe, P.H., Burczynski, J. and Youngbluth, M.J. (1988). Acoustical detection of high density krill demersal layer in the submarine canyons off George Bank. Science, 241: 359-361.

Greene, G.H., Weibe, P.H., Miyamoto, R.T. and Burczynski, J. (1991). Probing the fine structure of the ocean sound-scattering layer with ROVERSE technology. Limnol. Oceanogr., 36: 193-204.

Greene, G.H., Widder, E.A., Youngbluth, M.J., Tamse, A. and Johnson, G.E. (1992). The migration behavior, fine structure, and bioluminiscent activity of krill soundscattering layers. Limnol. Occanogr., 37: 650-658. compactabilidad, así cono determinar los patrones de distribución y movimientos de los principales componentes de la capa de dispersión profunda.

\section{AGRADECIMIENTOS}

Nuestro agradecimiento a los estudiantes del Laboratorio de Ecología de Pesquerías del ICMyL y a la tripulación del $\mathrm{B} / \mathrm{O}$ El Puma. Esta investigación fue linanciada por el Consejo Nacional de Ciencia y Tecnologia (CONACYT 0511-N9108) y por la Dirección de Estudios de Posgrado e Investigación (DEPI 903361). Los autores pertenecen al Sistema Nacional de Investigadores y el segundo autor adicionalmente a la beca de exclusividad COFAA-IPN.

Guerin-Ancey, O. and David, P.M. (1993). Use of a multibeam-multifrequency sounder to study the distribution of small zooplankton. Deep-Sea Res., 40: 119-128.

Hernández-Trujillo, S., Esquivel-Herrera, A., Saldierna-Martínez, R.J. (1987). Biomasa zooplanctónica de la costa oeste de Baja California Sur (1982-1985). En: M. Ramírez-Rodríguez (ed.), Simpósium sobre la Investigación en Biología y Oceanografía Pesquera en México. La Paz, BCS, México, pp. 161-169.

Hewitt, R.P., Smith, P.E. and Brown, J.C. (1976). Development and use of sonar mapping for pelagic stock assessment in the California Current area. Fish. Bull., 74: 281-297.

Lavaniegos-Espejo, B. (1994). Dispersion and development patterns in larvae of Nyctiphanes simplex (Euphausiacea) in the upwelling region of Baja California. Mar. Fcol. Prog. Ser., 106: 207-225.

Locb, I.V., Smith, P.E. and Moser, G.H. (1983). Gcographical and seasonal patterns of larval tish species structure in the California Current area, 1975. CALCOFI Rep., 24: 132-151.

MacLennan, D.N. and Simmonds, E.J. (1992). Fisheries Acoustics. Chapman \& Hall. London, $325 \mathrm{pp}$. 
Madurcira. L.S.P. Ward. P. and Atkinson, A. (1993). Differences in backscattering strength determined at 120 and $38 \mathrm{kll} /$ for three species of Antarctic macroplankton. Mar. Ecol. Prog. Ser. 93: 17-24.

Morton. K.l. and Macledlan. S.C. (1992) Acoustics and treshwater rooplankion. I. Plankton Res. 14: 1117-1127.

Napp, I.M. Ortner. P.B.. Pieper. R.E. and Holliday. D.V. (1993). Biovolume-size spectra of epipelagic zooplankton using a multifrequency acoustic proliling system (MAPS). Deep-Sea Res, 40: 445-459.

Pieper, R.E... Holliday. D.V. and Kleppel, G.S. (1990). Quantitative zooplankton distributions from multifrequency acoustics. I. Plankton Res. 12: 433-441.

Rocsler. C.S. and Chelton. D.B. (1987). Kooplankton variability in the California Current 1951 1982. CALCOHI Rep.. 28: 59-96.

Sameoto. D.I) (1980). Quantitative measurements of euphausiids using a $120-\mathrm{kHz}$ sounder and their in situ orientation. Can. I. Iish. Acuat. Sci., 37: 693-702.

Sameoto. D.D.. Jarosyynski. L.O. and Fraser. W. (. (1977). Distribution of cuphausids scattering layers in the Gulf of St. Lawrence estuary. Fish. Res. Board lech. Rep. 430: $1-17$.

Sancoto. D.D. Cochrane. N. and Herman, $\Lambda$. (1993) Convergence of acoustic. optical. and net-catch estimates of euphausid ahundance: Use of artificial light to reduce net avoidance. Can. J. Iish. Nquat. Sci. 50: 334-346

Schuly. II. (1976). Results of the "Mexal" program Pleturoncodes planipes (Stimpson) in the bottom trawl catches of the research ressel Bonn and Heser. Bundesformschunfsonstalt für lishherei. Ins. für Seefscherci. 1-4.

Smith. P.E. and Richardson. S.L. (1977). Standard techniques for pelagic fish and larvae surveys. FAO lish. Tech. Pap. 175: $1-107$.

Smith. P.l.. (Ohman, M.I) and Lber. L.F. (1989). Analysis of the patterns of distribution of zooplankton aggregations from an acoustic Doppler current profiler. CAICOFI Rep.. 30: 88-103.

Tucker, G.H. (1951). Relation of lishes and other organisms to the scattering of underwater sound. J. Mar. Res. 10:215-238

Walline. P.D., Pianty, $S$. and lindem, $T$. (1992). Acoustic assessment of the number of pelagic fish in Lake Kinneret. Isracl. Hydrobiologia. 231: 153-163.

Weibe. P.H., Greene. C.IJ., Stanton T.K. and Burcyynski. J. (1990). Sound scattering by life zooplankton and micronckton: Empirical with a dual-beam acoustical system. J. $\Lambda$ coust. Soc. Am.. 88: 2346-2360. 